\title{
Molecular Surveillance of Pfkelch13 and Pfmdr1 Mutations in Plasmodium falciparum Isolates from Southern Thailand
}

\author{
Thunchanok Khammanee ${ }^{1}$, Nongyao Sawangjaroen', Hansuk Buncherd², Aung Win Tun 3 , \\ Supinya Thanapongpichat ${ }^{2, *}$ \\ ${ }^{1}$ Department of Microbiology, Faculty of Science, Prince of Songkla University, Hat Yai, Songkhla, Thailand; ${ }^{2}$ Faculty of Medical Technology, Prince of
Songkla University, Hat Yai, Songkhla, Thailand: ${ }^{~}$ Faculty of Graduate Studies, Mahidol University, Salaya, Nakhon Pathom, Thailand
}

Abstract: Artemisinin-based combination therapy (ACT) resistance is widespread throughout the Greater Mekong Subregion. This raises concern over the antimalarial treatment in Thailand since it shares borders with Cambodia, Laos, and Myanmar where high ACT failure rates were reported. It is crucial to have information about the spread of ACT resistance for efficient planning and treatment. This study was to identify the molecular markers for antimalarial drug resistance: Pfkelch13 and Pfmdr1 mutations from 5 provinces of southern Thailand, from 2012 to 2017, of which 2 provinces on the Thai- Myanmar border (Chumphon and Ranong), one on Thai-Malaysia border (Yala) and 2 from non-border provinces (Phang Nga and Surat Thani). The results showed that C580Y mutation of Pfkelch13 was found mainly in the province on the Thai-Myanmar border. No mutations in the PfKelch13 gene were found in Surat Thani and Yala. The Pfmdr1 gene isolated from the Thai-Malaysia border was a different pattern from those found in other areas (100\% N86Y) whereas wild type strain was present in Phang Nga. Our study indicated that the molecular markers of artemisinin resistance were spread in the provinces bordering along the Thai-Myanmar, and the pattern of Pfmdr1 mutations from the areas along the international border of Thailand differed from those of the non-border provinces. The information of the molecular markers from this study highlighted the recent spread of artemisinin resistant parasites from the endemic area, and the data will be useful for optimizing antimalarial treatment based on regional differences.

Key words: PfKelch13, Pfmdr1, artemisinin resistance, Southern Thailand

\section{INTRODUCTION}

Malaria remains a leading health problem in many countries, particularly those in tropical and subtropical regions of the world [1]. The countries of Greater Mekong Subregion (GMS) (i.e., Thailand, Cambodia, Laos, Myanmar, Vietnam, and China) have developed resistance to antimalarial drugs [2] although they set the target to eliminate malaria by 2030 [3]. In the late 1950s, the chloroquine resistance was initially reported in the Cambodia-Thailand border. It was then followed by the resistance to sulfadoxine-pyrimethamine, mefloquine and quinine [4]. Artemisinin-based combination therapy (ACT), either with mefloquine, lumefantrine, or piperaquine, is adopted as the main line of treatment for uncompli-

- Received 12 November 2018, revised 6 June 2019, accepted 15 July 2019.

*Corresponding author (supinya.th@psu.ac.th)

(c) 2019, Korean Society for Parasitology and Tropical Medicine

This is an Open Access article distributed under the terms of the Creative Commons Attribution Non-Commercial License (http://creativecommons.org/licenses/by-nc/4.0) which permits unrestricted non-commercial use, distribution, and reproduction in any

medium, provided the original work is properly cited. cated falciparum malaria [5]. The artemisinin kills the asexual blood stage of the parasites and it rapidly clears parasites than any other antimalarial drugs could do $[6,7]$, while the partner drug eliminates the remaining parasites [8]. However, in 2006, the first observed reduction of parasites clearance was detected in patients from western Cambodia after an artemisinin therapy [9]. These cases confirmed that the artemisinin resistance had occurred along the Cambodia-Thailand border, the same area where chloroquine resistance was observed several decades ago $[5,10]$. Recently, the artemisinin resistance has already spread to 5 countries of the GMS [11]. Unfortunately, there is a simultaneous emergence of partner drug resistance, including resistance to artemether-lumefantrine, artesunateamodiaquine, artesunate-mefloquine and artesunate-sulfadoxine-pyrimethamine, resulting in high treatment failure rate along Cambodian-Thai, Cambodia-Laos, and Thai-Myanmar borders [12].

Mutations in PfKelch13 propeller region were usually associated with artemisinin-resistance [13] and the highly frequent mutations detected in the eastern GMS (Cambodia, Lao PDR, 
and Viet Nam) were C580Y, R539T, Y493H, and I543T. On the other hand, F446L, N458Y, P574L, and R561H mutations were common in the western GMS (China, Myanmar, and Thailand) [14]. Non-synonymous (NS) mutations in PfKelch13 gene such as Y493H, R539T, I543T, and C580Y are the established molecular markers for artemisinin resistance in P. falciparum [15]. The C580Y mutation was common in western Cambodia, north-eastern Thailand, and southern Laos. Mutations in P. falciparum multidrug resistance gene (Pfmdr1) caused different in vivo efficacy and in vitro $P$. falciparum susceptibility to ACT including amodiaquine $[16,17]$, mefloquine $[18,19]$, lumefantrine $[20,21]$ and artemisinin derivatives [19]. It was suggested that changes in sequence or copy number of Pfmdr 1 altered influx and efflux of several drugs in the parasite food vacuole [22]. The 5 common genotypes of Pfmdr1 were N86Y, Y184F, S1034C, N1042D, and D1246Y. Pfmdr1 N86Y mutation was associated with chloroquine and amodiaquine resistance [2-4], while Y184F mutation was common with increased resistance to mefloquine and artesunate [23]. Point mutations at S1034C, N1042D, and D1246Y have been reported as resistance to quinine and increased susceptibility to mefloquine, halofantrine, and artemisinin derivatives $[19,24,25]$.

Southern Thailand consists of 14 provinces with a population of about 8.7 million. It is in borders with Malaysia to the south and Myanmar to its upper west. In Malaysia, the incidence of malaria is estimated to be 13 cases per 100,000 populations [26] and the prevalence of antimalarial drug resistance was relatively low [27]. The molecular analysis showed a single copy of Pfmdr1 and wild-type PfKelch13 genes indicating that Malaysia has limited case of artemisinin resistance. However, the prevalence of malaria is higher in southern Thailand especially in areas bordering with the countries such as Myanmar. The dramatic increase of malaria cases in southern Thailand is attributed to its tropical rainforest, relatively higher proportion of migrant workers for rubber plantations from neighboring countries, and the prolonged insurgency in some provinces [4].

The aim of the present study is to analyze the molecular markers associated with $P$. falciparum resistance to antimalarial drugs in the Kelch13 and Pfmdr1 genes from the samples collected from Southern Thailand. The results would provide crucial evidence for further molecular surveillance of ACT in this part of the world. The information from this study can be used for efficient planning and targeting of malaria control in southern Thailand.

\section{MATERIALS AND METHODS}

\section{Blood collection}

The dried blood spots samples were received from the Office of Disease Prevention and Control 11 and 12, Thailand. The samples were collected from uncomplicated falciparum malaria patients when they attended their first visit to the malaria clinic and were positive on microscopic examination, but they did not have prior antimalarial treatment. Neither treatment outcome nor parasite clearance was followed up. The blood samples were obtained by finger-prick and spotted on filter paper (Whatman 3MM, GE Healthcare, Buckinghamshire, UK) for approximately $80 \mu \mathrm{l}$. Individual samples were stored in each plastic bag at room temperature before DNA extraction. DNA was extracted using QIAamp DNA Mini Kit (Qiagen, Hilden, Germany) according to the manufacturer's instructions. Genomic DNA was eluted into $100 \mu \mathrm{l}$ of elution buffer and used immediately or stored at $-20^{\circ} \mathrm{C}$ until use.

Ethical approval for this study was obtained from the Faculty of Medicine, Prince of Songkla University (REC60-096-19-2).

\section{Detection of PfKelch13 propeller gene}

The presence of $P$. falciparum was confirmed in all samples by nested PCR with species-specific primers based on 18s rRNA gene, as described by Snounou et al. [28]. P. falciparum kelch13 was amplified from the genomic DNA using nested PCR following the protocol previously described by Ariey et al. [13] with some modifications. In the first PCR, the full-length Pfkelch13 gene sequence $(1-2,283 \mathrm{bp})$ was amplified with a primer pair K13-1F (5'-TGGAAGGAGAAAAAGTAAAAACAAAA-3') and K132283R ( $5^{\prime}$-TGTGCATGAAAATAAATATTAAAGAAG-3'). The PCR product was then amplified into 3 fragments in the second PCR step. The length of fragment 1 was 718 bp using K13-1F (see above) and K13c694-R (5'-TCTCGAATAAAATTCATTTGTGTCTT-3'). The fragment 2 covered positions 621-1538 using the primers K13c621F ( $5^{\prime}$-CGGAATTAAGTGATGCTAGTGA-3') and K13c1538R (5'-CGATCATACACCTCAGTTTCAA- $3^{\prime}$ ) to produce 917 bp product. The third fragment was amplified at the nucleotide positions 1344-2129 with the primer pairs K13c1344F (5' -AGGTGGATTTGATGGTGTAGAA-3') and K13c2129R (5'-GGGCCAAGCTGCCATTCATTCATTTGT- $3^{\prime}$ ) to produce amplicons of 786 bp. In each PCR reaction, $5 \mu$ of genomic DNA was amplified in $25 \mu$ l of PCR master mix using $2 \mathrm{mM} \mathrm{MgCl}_{2}$ for first round PCR and $3 \mathrm{mM} \mathrm{MgCl}_{2}$ for second round PCR, $250 \mu \mathrm{M}$ of dNTPs, $250 \mathrm{nM}$ of oligonucleotide primers, 0.5 units of Platinum Taq 
DNA polymerase (Invitrogen, Carlsbad, California, USA), and 3 $\mu \mathrm{l}$ of PCR product from the first PCR for the second PCR. The first PCR was performed with an initial denaturation at $94^{\circ} \mathrm{C}$ for $5 \mathrm{~min}, 30$ cycles of denaturation at $94^{\circ} \mathrm{C}$ for $1 \mathrm{~min}$, annealing at $58^{\circ} \mathrm{C}$ for $2 \mathrm{~min}$, extension at $72^{\circ} \mathrm{C}$ for $2 \mathrm{~min}$ and the final extension at $72^{\circ} \mathrm{C}$ for $10 \mathrm{~min}$. The second PCR was done with 35 cycles of denaturation at $94^{\circ} \mathrm{C}$ for $1 \mathrm{~min}$, annealing for $2 \mathrm{~min}$ at $55^{\circ} \mathrm{C}$ for fragment 1 and $58^{\circ} \mathrm{C}$ for fragment 2 , extension at $72^{\circ} \mathrm{C}$ for 2 $\mathrm{min}$, and the final extension at $72^{\circ} \mathrm{C}$ for $5 \mathrm{~min}$. The PCR products were analyzed on a $2 \%$ agarose gel electrophoresis stained with $0.5 \mu \mathrm{g} / \mathrm{ml}$ ethidium bromide and visualized under UV light.

\section{Detection of Pfmdr1 gene}

Five mutations of the Pfmdr1 gene were amplified using the 2 primer pairs as described in the previous study [29]. The sequences of codons 86 and 184 were amplified with primer pairs MDR1F (5'-AGAGAAAAAAGATGGTAACCTCAG-3') and MDR1R (5'-ACCACAAACATAAATTAACGG-3') with an expected amplified amplicons length of $590 \mathrm{bp}$. The second amplicon was amplified with the primer pairs MDR2F (5'-GCGGAGTTTTTGCATTTAGTTCAGATGATG-3') and MDR2R (5' -AGCAGCAAACTTACTAACACGTTTAACATC- $3^{\prime}$ ) to have the fragment length of $968 \mathrm{bp}$ which contained the sequences of codons 1034, 1042, and 1246. The total reaction mixture of 25 $\mu \mathrm{l}$ consisted $1 \times$ PCR buffer, $3 \mathrm{mM} \mathrm{MgCl} 2,0.2 \mathrm{mM}$ of each deoxynucleotide triphosphate (dNTP), $0.2 \mu \mathrm{M}$ of each oligonucleotide primers, 0.5 units of Platinum Taq polymerase and 5 $\mu \mathrm{l}$ of DNA template. The target amplification of MDR1 was programmed for initial denaturation at $95^{\circ} \mathrm{C}$ for $5 \mathrm{~min}, 35 \mathrm{cy}$ cles of $95^{\circ} \mathrm{C}$ for $1 \mathrm{~min}, 55^{\circ} \mathrm{C}$ for $1.30 \mathrm{~min}, 72^{\circ} \mathrm{C}$ for $2 \mathrm{~min}$ and final extension at $72^{\circ} \mathrm{C}$ for $8 \mathrm{~min}$. For MDR2F/R, the conditions were an initial denaturation at $95^{\circ} \mathrm{C}$ for $3 \mathrm{~min}$ followed by 35 cycles of $93^{\circ} \mathrm{C}$ for $30 \mathrm{sec}, 53^{\circ} \mathrm{C}$ for $30 \mathrm{sec}, 72^{\circ} \mathrm{C}$ for $1 \mathrm{~min}$ and final extension at $72^{\circ} \mathrm{C}$ for $5 \mathrm{~min}$. The PCR products were evaluated by electrophoresis on a $1.5 \%$ agarose gel and visualized with ethidium bromide staining.

\section{Sequence analysis}

The PCR products of PfKelch13 and Pfmdr1 amplicons were cleaned using QIAquick PCR purification kit (Qiagen) before sequencing by ABI Sequencer (Macrogen, Seoul, Korea). DNA sequences were aligned using BioEdit v7.2.5 with the reference sequences PF3D7_1343700 for PfKelch13 and PF3D7_0523000 for Pfmdr1 respectively.

PCR or sequencing was repeated if the amplification was unsuccessful, or the sequence chromatogram was vague at some point. In addition, some of the samples were repeated for sequencing to confirm the result. Data analysis was performed using Microsoft Excel 2007 and analyzed by SPSS 19.0 (SPSS Inc., Chicago, Illinois, USA).

\section{RESULTS}

A total of 128 uncomplicated falciparum malaria samples were obtained from 5 provinces of Southern Thailand (Fig. 1) from 2012 to 2017. All the samples were divided into 2 groups according to their geographical locations. The first group was from the 3 provinces that shared a border with the neighboring countries of Thailand and the second group was from the 2 provinces which were not located at the Thai border. The first group consisted of 16 samples from Chumphon (10 samples in 2013, 6 samples in 2014), 40 samples from Ranong (8 samples in 2012, 13 samples in 2013, 19 samples in 2015) and 12 samples from Yala in 2017 respectively. Chumphon and Ranong provinces are located at the Thai-Myanmar border while Yala shares border with Malaysia. The second group had 60 samples which were from Phang Nga and Surat Thani provinces and comprised of 14 samples from Phang Nga (4 samples in 2012, 10 samples in 2015), and 46 samples from Surat Thani (17 samples in 2014, 19 samples in 2015, 10 samples in 2016). Table 1 summerises the molecular analysis of PfKelch13 and Pfmdr1 genes together with the respective year of sample collection.

\section{PfKelch13 mutations}

In this study, artemisinin resistance-confirmed mutations, C580Y and P574L were identified in provinces located at ThaiMyanmar border, Chumphon and Ranong, and in one nonborder province, Phang Nga. C580Y mutation was detected in 13 of 40 samples (32.5\%) from Ranong: 1 of 8 samples (12.5\%) in 2012 and 6 of 13 samples (46.15\%) in 2013 and 6 of 19 samples (31.58\%) in 2014, respectively. It is interesting to note that the samples from Phang Nga, only $230 \mathrm{~km}$ south of Ranong, showed C580Y mutation in 2 of 10 samples (20\%) in 2015. Chumphon province had P574L mutation in 1 of 6 samples (16.67\%) in 2014, and 10 samples received in 2013 had no PfKelch13 mutation. Two samples had more than one mutations in PfKelch13 gene from the samples of the same year 2012. Of these, one isolate from Ranong had the mutation at N554S/I590T, and the other isolate (1 of 4 samples) 


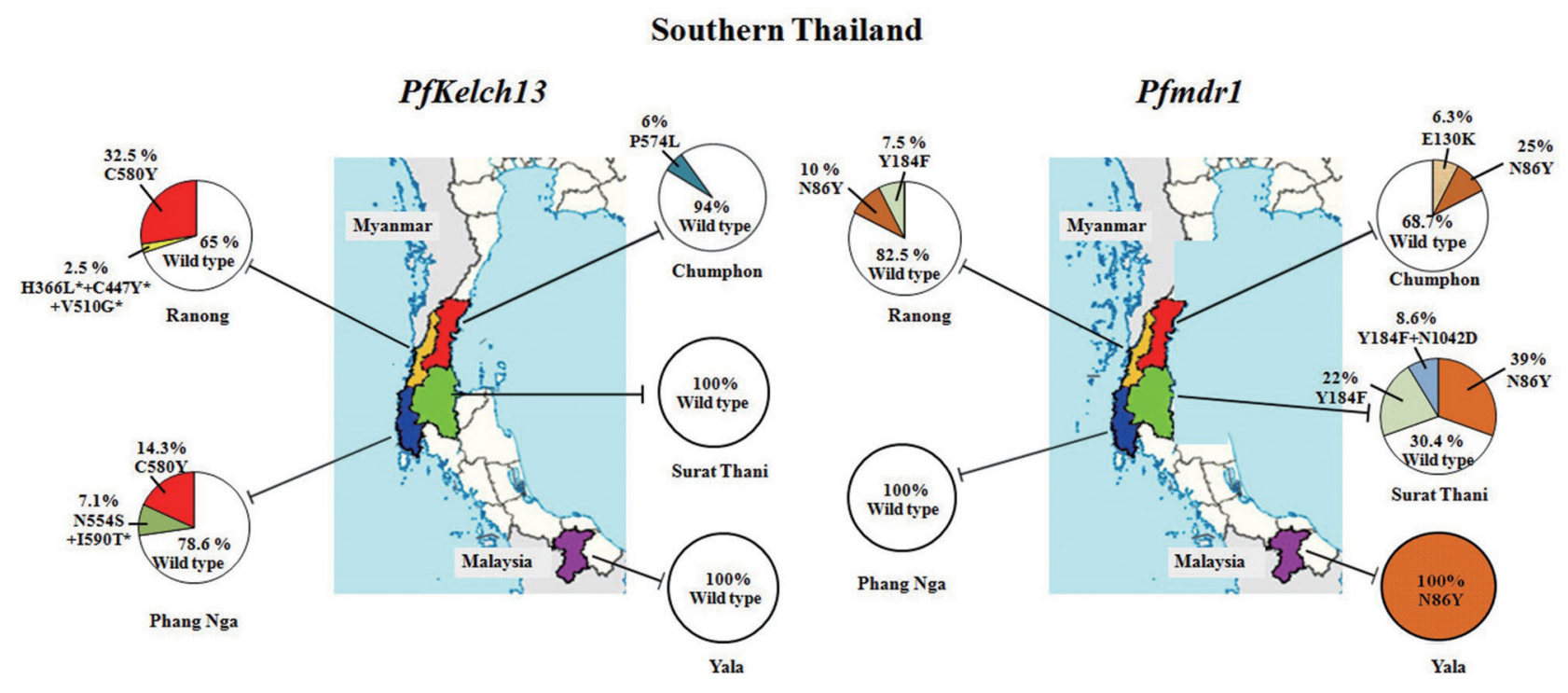

Fig. 1. Geographic distribution of P. falciparum Kelch13 and Pfmdr1 mutations collected in 5 provinces of Southern Thailand including 2 provinces on the Thai-Myanmar border (Chumphon and Ranong), 2 from non-border provinces (Surat Thani and Phang Nga) and 1 from Thai-Malaysia border (Yala). Pie charts show the percentages of the mutations in 2 genes observed among 128 parasite samples collected between 2012 and 2017.

Table 1. Summary of PfKelch13 and Pfmdr1 mutations identified in 5 southern provinces of Thailand together with the year of sample collection

\begin{tabular}{|c|c|c|c|c|c|c|c|c|c|c|c|}
\hline \multirow{2}{*}{$\begin{array}{l}\text { Parasite } \\
\text { isolates }\end{array}$} & \multirow[b]{2}{*}{ Year } & \multicolumn{5}{|c|}{$\begin{array}{c}\text { PfKelch13 } \\
\text { Amino acid position }\end{array}$} & \multicolumn{5}{|c|}{$\begin{array}{c}\text { Pfmdr1 } \\
\text { Amino acid position }\end{array}$} \\
\hline & & $\begin{array}{l}\text { wild-type } \\
(\%)\end{array}$ & $\begin{array}{c}\mathrm{H} 366 \mathrm{~L}^{*}+ \\
\mathrm{C} 447 \mathrm{Y}^{*}+ \\
\mathrm{V} 510 \mathrm{G}^{*}(\%)\end{array}$ & $\begin{array}{c}\text { N554S+ } \\
\text { I590T* }^{\star} \\
(\%)\end{array}$ & $\begin{array}{c}\text { P574L } \\
(\%)\end{array}$ & $\begin{array}{l}\text { C580Y } \\
(\%)\end{array}$ & $\begin{array}{l}\text { wild-type } \\
\text { (\%) }\end{array}$ & $\begin{array}{l}\text { N86Y } \\
(\%)\end{array}$ & $\begin{array}{c}\text { E130K } \\
(\%)\end{array}$ & $\begin{array}{l}\text { Y184F } \\
(\%)\end{array}$ & $\begin{array}{c}\text { Y184F+ } \\
\text { N1042D } \\
(\%)\end{array}$ \\
\hline \multirow[t]{2}{*}{ Chumphon } & $2013(n=10)$ & 10 (100) & - & - & - & - & $8(80)$ & $2(20)$ & - & - & - \\
\hline & $2014(n=6)$ & $5(83.3)$ & - & - & $1(16.67)$ & - & $3(50)$ & 2 (33.33) & $1(16.67)$ & - & - \\
\hline \multirow[t]{3}{*}{ Ranong } & $2012(n=8)$ & $6(75)$ & - & $1(12.5)$ & - & $1(12.5)$ & $8(100)$ & - & - & - & - \\
\hline & $2013(n=13)$ & 7 (53.85) & - & - & - & $6(46.15)$ & $9(69.23)$ & 3 (23.08) & - & 1 (7.69) & - \\
\hline & $2015(n=19)$ & $13(68.42)$ & - & - & - & $6(31.58)$ & $16(84.21)$ & 1 (5.26) & - & $2(10.53)$ & \\
\hline \multirow[t]{2}{*}{ Phang Nga } & $2012(n=4)$ & $3(75)$ & $1(25)$ & - & - & - & $4(100)$ & - & - & - & - \\
\hline & $2015(n=10)$ & $8(80)$ & - & - & - & $2(20)$ & $10(100)$ & - & - & - & - \\
\hline \multirow[t]{3}{*}{ Surat Thani } & $2014(n=17)$ & $17(100)$ & - & - & - & - & 7 (41.18) & 7 (41.18) & - & $3(17.64)$ & - \\
\hline & $2015(n=19)$ & $19(100)$ & - & - & - & - & $7(36.84)$ & $4(21.05)$ & - & 5 (26.32) & 3 (15.78) \\
\hline & $2016(n=10)$ & $10(100)$ & - & - & - & - & - & $7(70)$ & - & $2(20)$ & $1(10)$ \\
\hline Yala & $2017(n=12)$ & $12(100)$ & - & - & - & - & - & $12(100)$ & - & - & - \\
\hline Total & 128 & 110 & 1 & 1 & 1 & 15 & 72 & 38 & 1 & 13 & 4 \\
\hline
\end{tabular}

*Novel mutation.

Chumphon, $n=16$; Ranong, $n=40$; Phang Nga, $n=14$; Surat Thani, $n=46$; Yala, $n=12$.

from Phang Nga had H366L+C447Y+V510G, the 3 mutations present in a single sample which had not been detected elsewhere. Of these mutations, N554S has been reported from Mali in 2011 [30] and Ungoye, Kenya, in 2012 [31]. Unlike themutation of PfKelch13 presented on Thai-Myanmar border, P. falciparum circulated in Thai-Malaysia border, Yala in 2017, had $100 \%$ wild-type on PfKelch13 polymorphism. Forty-six isolates in 2014-2016 from Surat Thani, the non-border province had no evidence of molecular markers associated with artemisinin resistance.

\section{Pfmdr1 mutations}

Out of 128 samples, 72 samples (56.25\%) showed the Pfm$d r 1$ wild-type while 38 samples (29.69\%) had N86Y muta- 
tion. Less frequently, E130K was observed in 1 (0.78\%), Y184F in $13(10.16 \%)$, and Y184F plus N1042D in $4(3.12 \%)$ samples respectively. However, mutations at S1034C and D1246Y were not identified in the present study. Two provinces along the Thai Myanmar border, Chumphon and Ranong had the N86Y mutation in 20\% (2/10 samples) in 2013, 33.33\% (2/6 samples) in 2014, 23.08\% (3/13 samples) in 2013, and 5.26\% (1/19 samples) in 2015, respectively whereas Pfmdr1 Y184F mutation was detected in 7.69\% (1/13 samples) in 2013 and $10.53 \%$ (2/19 samples) in 2015, but this mutation was not found in Chumphon. E130K was found in one isolated from Chumphon in 2014. This study was the first report of Pfmdr1 isolated from parasites in Surat Thani province. The N86Y mutation was observed in 7/17 samples (41.18\%) in 2014, 4/19 samples (21.05\%) in 2015 and 7/10 samples (70\%) in 2016 respectively. For Y184F mutation, it was detected for $17.6 \%$ in 2014 (3/17 samples), 26.3\% in 2015 (5/19 samples) and 20\% in 2016 (2/10 samples) respectively. Double mutant genotypes Y184F plus N1042D appeared in the present study for $15.7 \%$ in 2015 (3/19 samples) and 10\% in 2016 (1/10 samples). No mutations on Pfmdr1 gene associated with multidrug resistance were identified in the parasites isolated from Phang Nga province. However, in Yala province (Thai-Malaysia border), the point mutation N86Y in Pfmdr1 was present in $100 \%$ of the isolates.

\section{DISCUSSION}

Several studies have reported the mutations conferring drug resistance was commonly present in the area such as ThaiCambodian, Thai-Myanmar and Thai-Laos borders. Drug resistance in malaria is frequently checked using molecular markers such as PfKelch13 gene for Artemisinin resistance, and P. falciparum multidrug resistance1 gene, for the partner drugs resistance such as chloroquine mefloquine, lumefantrine and quinine [32]. Since the last decade, the increasing prevalence of confirmed mutations for artemisinin resistance in PfKelch13 have been reported along the Thai-Cambodia and Thai-Myanmar borders, and in the GMS region [13,14,33-35]. The people with subclinical infection carrying the resistant $P$. falciparum allele might contribute to the spread of artemisinin-resistant gene to Thailand via cross-border movements. Mae Hong Son, one of the northwestern provinces, and Surat Thani and Yala provinces in southern Thailand have limited artemisinin-resistant genes [36] even though they are in the endemic area and are mainly rural, forested and bordering with Myanmar. Hence, it is crucial to monitor the current status of artemisinin resistance in the region using molecular markers as well as therapeutic efficacy, especially in an area where we have limited knowledge for $P$. falciparum drug resistance.

Since 2009, the first-line treatment for uncomplicated $P$. falciparum infections had been changed from 2-days artesunateplus-mefloquine to 3-days regimen in eastern and western Thailand $[5,15,37]$. However, widespread mefloquine resistance has been reported in Thailand because it was used as monotherapy over the last few decades. Data from the present study revealed the PfKelch13 and Pfmdr1 mutations from 5 Thailand provinces, collected from 2012 to 2017. We divided the sample into 2 groups: the first group contains samples from the 3 provinces bordering with 2 countries and the second group from the 2 provinces that do not share a border with any other country. The prevalence of PfKelch13 artemisinin resistance-confirmed mutations, C580Y mutation, mainly found in the provinces located at Thailand-Myanmar border, especially in Ranong, was compared with other sites in this study. The result was consistent with the previous studies [36,38]. Phang Nga, the neighboring province of Ranong, had C580Y mutation in samples collected in 2015. However, the previous study by Putaporntip et al. [39] has reported that Kelch13 mutation in P. falciparum collected in Phang Na at 2009 was wild type. Our result suggested that the spread of artemisinin-resistance in Phang Nga province might be due to the cross-border movements, and mobile populations of people who involved in forest-related activities from Ranong province.

Recently, the study by Kobasa et al. [36] has found that $P$. falciparum carrying C580Y mutation was present in the samples collected from Chumphon (Thailand-Myanmar border) in 2007. The present study found that P574L mutation, another confirmed mutation for artemisinin resistance [40], was found in Chumphon province in samples from 2014. This mutation was highly prevalent in neighboring countries such as Myanmar and China [41]. In contrast, there was no evidence of PfKelch13 resistance-confirmed mutations in samples from Yala (2017), which is located at the Thailand-Malaysia border. This result was concordant with the previous report in 2015 [40]. In addition, the parasite isolates from Surat Thani, the non-border province also had no mutations in PfKelch13 gene. Our study also indicated that no molecular makers confirmed for artemisinin resistance were detected in Surat Thani and Yala provinces. 
Table 2. Comparison of molecular surveillance on artemisinin resistance and multidrug resistance of Plasmodium falciparum between the present studies and other studies

\begin{tabular}{|c|c|c|c|c|}
\hline \multirow[t]{2}{*}{ Mutation } & $\begin{array}{c}\text { Present study } \\
\text { (Southern Thailand) }\end{array}$ & $\begin{array}{l}\text { Mungthin et al. } 2014 \text { [43] } \\
\text { (Southern Thailand) }\end{array}$ & $\begin{array}{l}\text { Imwong et al. } 2015 \text { [42] } \\
\text { (Ubon Ratchathani) }\end{array}$ & $\begin{array}{l}\text { Kobasa et al. } 2018 \text { [36] } \\
\text { (Thailand) }\end{array}$ \\
\hline & $2012-2017$ & 2009 & 2014 & $2012-2018$ \\
\hline \multicolumn{5}{|l|}{ PfKelch13 gene } \\
\hline No. of sample & 128 & ND & 88 & 277 \\
\hline Wild-type (\%) & $110(85.94)$ & ND & $6(6.82)$ & $121(43.68)$ \\
\hline $\mathrm{H} 366 \mathrm{~L}+\mathrm{C} 447 \mathrm{Y}+\mathrm{V} 510 \mathrm{G}^{*}(\%)$ & $1(0.78)$ & ND & - & - \\
\hline N458Y (\%) & - & ND & & $3(1.08)$ \\
\hline R539T (\%) & - & ND & $17(19.32)$ & 6 \\
\hline N554S+1590T (\%) & $1(0.78)$ & ND & & - \\
\hline P574L (\%) & $1(0.78)$ & ND & - & - \\
\hline C580Y (\%) & $15(11.72)$ & ND & $65(73.86)$ & 107 (38.63) \\
\hline $\mathrm{R} 561 \mathrm{H}(\%)$ & - & ND & - & $10(3.61)$ \\
\hline Other mutations (\%) & - & ND & - & $30(10.83)$ \\
\hline \multicolumn{5}{|l|}{ Pfmdr1 gene } \\
\hline No. of sample & 128 & 558 & 47 & ND \\
\hline Wild-type (\%) & 69 (53.9) & - & $8(17.02)$ & ND \\
\hline N86Y (\%) & $38(29.7)$ & $498(89.25)$ & - & ND \\
\hline E130K (\%) & $1(0.8)$ & - & - & ND \\
\hline Y184F (\%) & $13(10.2)$ & $58(10.39)$ & 39 (82.98) & ND \\
\hline S1034C & - & $2(0.36)$ & - & ND \\
\hline N1042D & - & - & - & ND \\
\hline $1246 Y$ & - & - & - & ND \\
\hline Y184F+N1042D (\%) & $4(3.1)$ & - & - & ND \\
\hline
\end{tabular}

ND, Not determined.

Table 2 describes the comparison of different patterns of molecular markers for artemisinin resistance and multidrug resistance between the present study and the other studies. In general, the predominant genotype of $P$. falciparum isolates in Southern Thailand is the wild type for PfKelch13 gene (85.94\%) except for those from Ranong province (11.72\%), the province located on Thai-Myanmar border. The recent study indicates the higher percentage of C580Y mutation (38.63\%) [36] in the eastern part of Thailand such as Sisaket and Ubon Ratchathani [42] which are close to Cambodia and, Kanchanaburi and Ranong which are at Myanmar border. This implies that the artemisinin-resistant C580Y of P. falciparum was distributed differently between the Myanmar-Thailand and Cambodia-Thailand border regions, with southern Thailand.

Since 2015, the first-line treatment for uncomplicated $P$. falciparum infections in Thailand had been dihydroartemisinin combined with piperaquine (DHA-PQ) [40] which can replace artesunate-mefloquine treatment. However, in vitro and in vivo resistance to mefloquine was highly correlated with the higher copy number of Pfmdr1. The mean copy number of Pfmdr1 in the lower southern region, Yala, was 1.2 while in
Ranang, bordering with Myanmar was 2.3 [43]. The distribution of polymorphisms in our study demonstrated that Pfmdr1 isolated from Yala province showed a single pattern N86Y mutation. The samples from Ranong in 2013 and 2014 had the mutations N86Y and Y184F respectively. These results were similar to the results of previous studies by Pickard et al. [23] and Mungthin et al. [43]. Pfmdr1 isolated from Chumphon province in 2014 had only E130K mutation. This mutation was previously recorded in the Cambodia-Vietnam [44] and Thai-Myanmar borders [45]. In Surat Thani province, the mutation of the Pfmdr1 gene was found at N86Y, Y184F, and Y184F plus N1042D positions. Our report would be the first report of mutation profile of Pfmdr1 gene from Surat Thani province. The pattern of Pfmdr1 gene mutations of $P$. falciparum were similar to the previous study by Mungthin et al. [43], showing that the frequency of N86Y were higher than those of Y184F mutation. In contrast the parasites from east of Thailand carried higher frequency of Y184F [42] (Table 2). However, in the present study, the parasites, isolates of the Pfmdr1 gene were wild type strain distributing in all provinces except for Yala province (N86Y, 100\%). 
Recently, N86Y and N1042N, SNPs in the Pfmdr1, exhibited a significant reduction of in vitro piperaquine sensitivity while copy number of Pfmdr1 mutations had no effect on piperaquine susceptibility [46]. According to our findings, the pattern of Pfmdr1 isolates from southern Thailand would be mefloquine sensitive but resistant to chloroquine, and those parasites containing the Pfmdr1 N86Y allele would exhibit significant reduction of piperaquine sensitivity. Most parasitic strains isolated from the present study showed the Pfmdr1 N86Y and Y184F mutation from Ranong and Surat Thani were different from those circulated in Ubon Ratchathani, which shares borders with Southern Laos and Northern Cambodia [42] suggesting that the Pfmdr1 mutations isolated from different areas in Thailand carried the different patterns. Hence, both in vivo and in vitro efficacy studies for antimalarial drug monitoring should be done with the samples fromdifferent parts of Thailand.

In summary, the genotyping data in Klech13 gene collected from southern Thailand during 2012-2017 indicated that Ranong province might be responsible for the spread the mutant allele to other areas of the southern Thailand with human movement. This result is supported by the data that approximately half of the malaria cases in Thailand were found in foreign migrant workers, and Ranong province harbors a substantial population of migrant workers in Thailand. This study reported for the first time that $\mathrm{C} 580 \mathrm{Y}$ mutation was found in Phang Nga among the samples from 2015. This would be the recent spread of artemisinin resistance allele from Ranong province which has a high frequency of $\mathrm{C} 580 \mathrm{Y}$ mutation. The result of SNP patterns in Pfmdr1 is helpful for researchers to monitor changes in parasite genotypes after a change in the treatment regimen. In addition, this data will also provide information for selection of anti-malarial drug policy in Thailand; new candidate drugs should be adopted at least based on the genotype of the parasites in different areas of Thailand.

\section{ACKNOWLEDGMENTS}

This work was supported by a grant from Prince of Songkla University, contract no. MET600576S, and the Faculty of Science Research Fund, Prince of Songkla University, contract no. 1-2558-02-008.

\section{CONFLICT OF INTEREST}

The authors declare no conflicts of interest.

\section{REFERENCES}

1. World Health Organization. World Malaria Report 2015 [Internet]; [cited 2018 Aug 2]; Available from: http://www.who.int/ malaria/publications/world-malaria-report-2015/en/.

2. Wongsrichanalai C, Meshnick SR. Declining artesunate-mefloquine efficacy against falciparum malaria on the CambodiaThailand border. Emerg Infect Dis 2008; 14: 716-719.

3. World Health Organization. Strategy for malaria elimination in the Greater Mekong Subregion: 2015-2030 [Internet]; [cited 2018 Aug 3]. Available from: http://iris.wpro.who.int/handle/10665.1/10945.

4. USAID. President's Malaria Initiative Greater Mekong Sub-region: Malaria Operational Plan FY 2017 [Internet]; [cited 2018 Aug 3]. Available from: https://www.pmi.gov/docs/defaultsource/default-document-library/malaria-operational-plans/ fy17/fy-2017-greater-mekong-subregion-malaria-operationalplan.pdf?sfvrsn=12.

5. Dondorp AM, Nosten F, Yi P, Das D, Phyo AP, Tarning J, Lwin KM, Ariey F, Hanpithakpong W, Lee SJ, Ringwald P, Silamut K, Imwong M, Chotivanich K, Lim P, Herdman T, An SS, Yeung S, Singhasivanon P, Day NP, Lindegardh N, Socheat D, White NJ. Artemisinin resistance in Plasmodium falciparum malaria. N Engl J Med 2009; 361: 455-467.

6. Dondorp A, Nosten F, Stepniewska K, Day N, White N. Artesunate versus quinine for treatment of severe falciparum malaria: a randomised trial. Lancet 2005; 366: 717-725.

7. Dondorp AM, Fanello CI, Hendriksen IC, Gomes E, Seni A, Chhaganlal KD, Bojang K, Olaosebikan R, Anunobi N, Maitland K, Kivaya E, Agbenyega T, Nguah SB, Evans J, Gesase S, Kahabuka C, Mtove G, Nadjm B, Deen J, Mwanga-Amumpaire J, Nansumba M, Karema C, Umulisa N, Uwimana A, Mokuolu OA, Adedoyin OT, Johnson WB, Tshefu AK, Onyamboko MA, Sakulthaew T, Ngum WP, Silamut K, Stepniewska K, Woodrow CJ, Bethell D, Wills B, Oneko M, Peto TE, von Seidlein L, Day NP, White NJ. Artesunate versus quinine in the treatment of severe falciparum malaria in African children (AQUAMAT): an openlabel, randomised trial. Lancet 2010; 376: 1647-1657.

8 . White N. Antimalarial drug resistance and combination chemotherapy. Philos Trans R Soc Lond B Biol Sci 1999; 354: 739-749.

9. World Health Organization. Status Report on Artemisinin Resistance [Internet]; [cited 2018 Aug 12]. Available from: http:// www.who.int/malaria/publications/atoz/status-rep-artemisininresistance-sept2015.pdf.

10. Noedl H, Se Y, Schaecher K, Smith BL, Socheat D, Fukuda MM. Evidence of artemisinin-resistant malaria in western Cambodia. N Engl J Med 2008; 359: 2619-2620.

11. Asia Pacific Malaria Elimination Network 2014. [Internet]; [cited 2018 Aug 12]. Available from: http://www.apmen.org.

12. Phyo AP, Ashley EA, Anderson TJC, Bozdech Z, Carrara VI, Sriprawat K, Nair S, White MM, Dziekan J, Ling C, Proux S, Konghahong K, Jeeyapant A, Woodrow CJ, Imwong M, McGready R, Lwin KM, Day NPJ, White NJ, Nosten F. Declining efficacy of ar- 
temisinin combination therapy against $P$. Falciparum malaria on the Thai-Myanmar border (2003-2013): the role of parasite genetic factors. Clin Infect Dis 2016; 63: 784-791.

13. Ariey F, Witkowski B, Amaratunga C, Beghain J, Langlois AC, Khim N, Kim S, Duru V, Bouchier C, Ma L, Lim P, Leang R, Duong S, Sreng S, Suon S, Chuor CM, Bout DM, Ménard S, Rogers WO, Genton B, Fandeur T, Miotto O, Ringwald P, Le Bras J, Berry A, Barale JC, Fairhurst RM, Benoit-Vical F, Mercereau-Puijalon O, Ménard D. A molecular marker of artemisinin-resistant Plasmodium falciparum malaria. Nature 2014; 505: 50-55.

14. World Health Organization. Status Report on Artemisinin and ACT Resistance [Internet]; [cited 2018 Aug 23]. https://www. who.int/malaria/publications/atoz/artemisinin-resistanceapril2017/en/.

15. Ashley EA, Dhorda M, Fairhurst RM, Amaratunga C, Lim P, Suon S, Sreng S, Anderson JM, Mao S, Sam B, Sopha C, Chuor CM, Nguon C, Sovannaroth S, Pukrittayakamee S, Jittamala P, Chotivanich K, Chutasmit K, Suchatsoonthorn C, Runcharoen R, Hien TT, Thuy-Nhien NT, Thanh NV, Phu NH, Htut Y, Han KT, Aye KH, Mokuolu OA, Olaosebikan RR, Folaranmi OO, Mayxay M, Khanthavong M, Hongvanthong B, Newton PN, Onyamboko MA, Fanello CI, Tshefu AK, Mishra N, Valecha N, Phyo AP, Nosten F, Yi P, Tripura R, Borrmann S, Bashraheil M, Peshu J, Faiz MA, Ghose A, Hossain MA, Samad R, Rahman MR, Hasan MM, Islam A, Miotto O, Amato R, MacInnis B, Stalker J, Kwiatkowski DP, Bozdech Z, Jeeyapant A, Cheah PY, Sakulthaew T, Chalk J, Intharabut B, Silamut K, Lee SJ, Vihokhern B, Kunasol C, Imwong M, Tarning J, Taylor WJ, Yeung S, Woodrow CJ, Flegg JA, Das D, Smith J, Venkatesan M, Plowe CV, Stepniewska K, Guerin PJ, Dondorp AM, Day NP, White NJ. Spread of artemisinin resistance in Plasmodium falciparum malaria. N Engl J Med 2014; 371: 411-423.

16. Holmgren G, Gil JP, Ferreira PM, Veiga MI, Obonyo CO, Björkman A. Amodiaquine resistant Plasmodium falciparum malaria in vivo is associated with selection of $p f c r t 76 \mathrm{~T}$ and $p f m d r 1$ 86Y. Infect Genet Evol 2006; 6: 309-314.

17. Sá JM, Twu O, Hayton K, Reyes S, Fay MP, Ringwald P, Wellems TE. Geographic patterns of Plasmodium falciparum drug resistance distinguished by differential responses to amodiaquine and chloroquine. Proc Natl Acad Sci USA 2009; 106: 18883-18889.

18. Reed MB, Saliba KJ, Caruana SR, Kirk K, Cowman AF. Pgh1 modulates sensitivity and resistance to multiple antimalarials in Plasmodium falciparum. Nature 2000; 403: 906-909.

19. Sidhu AB, Valderramos SG, Fidock DA. pfmdr1 mutations contribute to quinine resistance and enhance mefloquine and artemisinin sensitivity in Plasmodium falciparum. Mol Microbiol 2005; 57: 913-926.

20. Sisowath C, Ferreira PE, Bustamante LY, Dahlström S, Mårtensson A, Björkman A, Krishna S, Gil JP. The role of pfmdr1 in Plasmodium falciparum tolerance to artemether-lumefantrine in Africa. Trop Med Int Health 2007; 12: 736-742.

21. Veiga MI, Dhingra SK, Henrich PP, Straimer J, Gnädig N, Uhlemann AC, Martin RE, Lehane AM, Fidock DA. Globally preva- lent PfMDR1 mutations modulate Plasmodium falciparum susceptibility to artemisinin-based combination therapies. Nat Commun 2016; 7: 11553.

22. Koenderink JB, Kavishe RA, Rijpma SR, Russel FG. The ABCs of multidrug resistance in malaria. Trends Parasitol 2010; 26: 440446.

23. Pickard AL, Wongsrichanalai C, Purfield A, Kamwendo D, Emery K, Zalewski C, Kawamoto F, Miller RS, Meshnick SR. Resistance to antimalarials in Southeast Asia and genetic polymorphisms in pfmdr1. Antimicrob Agents Chemother 2003; 47: 2418-2423.

24. Humphreys GS, Merinopoulos I, Ahmed J, Whitty CJ, Mutabingwa TK, Sutherland CJ, Hallett RL. Amodiaquine and artemether-lumefantrine select distinct alleles of the Plasmodium falciparum $m d r 1$ gene in Tanzanian children treated for uncomplicated malaria. Antimicrob Agents Chemother 2007; 51: 991-997.

25. Lekostaj JK, Amoah LE, Roepe PD. A single S1034C mutation confers altered drug sensitivity to PfMDR1 ATPase activity that is characteristic of the 7G8 isoform. Mol Biochem Parasitol 2008; 157: 107-111.

26. Ministry of Health Malaysia. Health indicators 2014. Malaysia: 2014. Report Number: ISSN 1511-4589 MOH/S/RAN/74.14(TR).

27. Norahmad NA, Mohd Abd Razak MR, Abdullah NR, Sastu UR, Imwong M, Muniandy PK, Saat MN, Muhammad A, Jelip J, Tikuson M, Yusof N, Rundi C, Mudin RN, Syed Mohamed AF. Prevalence of Plasmodium falciparum molecular markers of antimalarial drug resistance in a residual malaria focus area in Sabah, Malaysia. PLoS One 2016; 11: e0165515.

28. Snounou G, Viriyakosol S, Zhu XP, Jarra W, Pinheiro L, do Rosario VE, Thaithong S, Brown $\mathrm{KN}$. High sensitivity of detection of human malaria parasites by the use of nested polymerase chain reaction. Mol Biochem Parasitol 1993; 61: 315-320.

29. Basco LK, Ringwald P. Molecular epidemiology of malaria in Cameroon. X. Evaluation of $p f m d r 1$ mutations as genetic markers for resistance to amino alcohols and artemisinin derivatives. Am J Trop Med Hyg 2002; 66: 667-671.

30. Fairhurst RM. Understanding artemisinin-resistant malaria: what a difference a year makes. Curr Opin Infect Dis 2015; 28: 417-425.

31. Isozumi R, Uemura H, Kimata I, Ichinose Y, Logedi J, Omar AH, Kaneko A. Novel mutations in K13 propeller gene of artemisinin resistant Plasmodium falciparum. Emerg Infect Dis 2015; 21: 490492.

32. Wurtz N, Fall B, Pascual A, Fall M, Baret E, Camara C, Nakoulima A, Diatta B, Fall KB, Mbaye PS, Diémé Y, Bercion R, Wade B, Pradines B. Role of Pfmdr1 in in vitro Plasmodium falciparum susceptibility to chloroquine, quinine, monodesethylamodiaquine, mefloquine, lumefantrine, and dihydroartemisinin. Antimicrob Agents Chemother 2014; 58: 7032-7040.

33. Imwong M SK, Kunasol C, Sutawong K, Mayxay M, Rekol H, Smithuis FM, Hlaing TM, Tun KM, van der Pluijm RW, Tripura R, Miotto O, Menard D, Dhorda M, Day NPJ, White NJ, Dondorp AM. The spread of artemisinin-resistant Plasmodium falciparum in the Greater Mekong subregion: a molecular epidemiol- 
ogy observational study. Lancet Infect Dis 2017; 17: 491-497.

34. Miotto O, Almagro-Garcia J, Manske M, Macinnis B, Campino S, Rockett KA, Amaratunga C, Lim P, Suon S, Sreng S, Anderson JM, Duong S, Nguon C, Chuor CM, Saunders D, Se Y, Lon C, Fukuda MM, Amenga-Etego L, Hodgson AV, Asoala V, Imwong M, Takala-Harrison S, Nosten F, Su XZ, Ringwald P, Ariey F, Dolecek C, Hien TT, Boni MF, Thai CQ, Amambua-Ngwa A, Conway DJ, Djimdé AA, Doumbo OK, Zongo I, Ouedraogo JB, Alcock D, Drury E, Auburn S, Koch O, Sanders M, Hubbart C, Maslen G, Ruano-Rubio V, Jyothi D, Miles A, O'Brien J, Gamble C, Oyola SO, Rayner JC, Newbold CI, Berriman M, Spencer CC, McVean G, Day NP, White NJ, Bethell D, Dondorp AM, Plowe $\mathrm{CV}$, Fairhurst RM, Kwiatkowski DP. Multiple populations of artemisinin-resistant Plasmodium falciparum in Cambodia. Nat Genet 2013; 45: 648-655.

35. Miotto O, Amato R, Ashley EA, MacInnis B, Almagro-Garcia J, Amaratunga C, Lim P, Mead D, Oyola SO, Dhorda M, Imwong M, Woodrow C, Manske M, Stalker J, Drury E, Campino S, Amenga-Etego L, Thanh TN, Tran HT, Ringwald P, Bethell D, Nosten F, Phyo AP, Pukrittayakamee S, Chotivanich K, Chuor CM, Nguon C, Suon S, Sreng S, Newton PN, Mayxay M, Khanthavong M, Hongvanthong B, Htut Y, Han KT, Kyaw MP, Faiz MA, Fanello CI, Onyamboko M, Mokuolu OA, Jacob CG, Takala-Harrison S, Plowe CV, Day NP, Dondorp AM, Spencer CC, McVean G, Fairhurst RM, White NJ, Kwiatkowski DP. Genetic architecture of artemisinin-resistant Plasmodium falciparum. Nat Genet 2015; 47: 226-234.

36. Kobasa T, Talundzic E, Sug-Aram R, Boondat P, Goldman IF, Lucchi NW, Dharmarak P, Sintasath D, Fukuda M, Whistler T, MacArthur J, Udhayakumar V, Prempree P, Chinanonwait N. Emergence and Spread of kelch13 Mutations Associated with Artemisinin Resistance in Plasmodium falciparum Parasites in 12 Thai Provinces from 2007 to 2016. Antimicrob Agents Chemother 2018; 62: e02141-17.

37. Noedl H, Se Y, Schaecher K, Smith BL, Socheat D, Fukuda MM. Evidence of artemisinin-resistant malaria in western Cambodia. N Engl J Med 2008; 359: 2619-2620.

38. Ye R, Hu D, Zhang Y, Huang Y, Sun X, Wang J, Chen X, Zhou H, Zhang D, Mungthin M, Pan W. Distinctive origin of artemisininresistant Plasmodium falciparum on the China-Myanmar border. Sci Rep 2016; 6: 20100.

39. Putaporntip C, Kuamsab N, Kosuwin R, Tantiwattanasub W, Vejakama P, Sueblinvong T, Seethamchai S, Jongwutiwes S, Hughes AL. Natural selection of K13 mutants of Plasmodium falciparum in response to artemisinin combination therapies in Thailand. Clin Microbiol Infect 2016; 22: 285. e1-8.

40. Talundzic E, Okoth SA, Congpuong K, Plucinski MM, Morton L,
Goldman IF, Kachur PS, Wongsrichanalai C, Satimai W, Barnwell JW, Udhayakumar V. Selection and spread of artemisininresistant alleles in Thailand prior to the global artemisinin resistance containment campaign. PLoS Pathog 2015; 11: e1004789.

41. Ménard D, Khim N, Beghain J, Adegnika AA, Shafiul-Alam M, Amodu O, Rahim-Awab G, Barnadas C, Berry A, Boum Y, Bustos MD, Cao J, Chen JH, Collet L, Cui L, Thakur GD1 Dieye A, Djallé $\mathrm{D}$, Dorkenoo MA, Eboumbou-Moukoko CE, Espino FE, Fandeur T, Ferreira-da-Cruz MF, Fola AA, Fuehrer HP, Hassan AM, Herrera S, Hongvanthong B, Houzé S, Ibrahim ML, JahirulKarim M, Jiang L, Kano S, Ali-Khan W, Khanthavong M, Kremsner PG, Lacerda M, Leang R, Leelawong M, Li M1, Lin K, Mazarati JB, Ménard S, Morlais I, Muhindo-Mavoko H, Musset L, Na-Bangchang K, Nambozi M, Niaré K, Noedl H, Ouédraogo JB, Pillai DR, Pradines B, Quang-Phuc B, Ramharter M, Randrianarivelojosia M, Sattabongkot J, Sheikh-Omar A, Silué KD, Sirima SB, Sutherland C, Syafruddin D, Tahar R, Tang LH, Touré OA, Tshibangu-wa-Tshibangu P, Vigan-Womas I, Warsame M, Wini L, Zakeri S, Kim S, Eam R, Berne L, Khean C, Chy S, Ken M, Loch K, Canier L, Duru V, Legrand E, Barale JC, Stokes B, Straimer J, Witkowski B, Fidock DA, Rogier C, Ringwald P, Ariey F, Mercereau-Puijalon O. A Worldwide Map of Plasmodium falciparum K13-Propeller Polymorphisms. N Engl J Med 2016; 374: 24532464.

42. Imwong M, Jindakhad T, Kunasol C, Sutawong K, Vejakama $P$, Dondorp AM. An outbreak of artemisinin resistant falciparum malaria in Eastern Thailand. Sci Rep 2015; 5: 17412.

43. Mungthin M, Intanakom S, Suwandittakul N, Suida P, Amsakul S, Sitthichot N, Thammapalo S, Leelayoova S. Distribution of pfmdr1 polymorphisms in Plasmodium falciparum isolated from Southern Thailand. Malar J 2014; 13: 117.

44. Khim N, Bouchier C, Ekala MT, Incardona S, Lim P, Legrand E, Jambou R, Doung S, Puijalon OM, Fandeur T. Countrywide survey shows very high prevalence of Plasmodium falciparum multilocus resistance genotypes in Cambodia. Antimicrob Agents Chemother 2005; 49: 3147-3152.

45. Imwong M, Dondorp AM, Nosten F, Yi P, Mungthin M, Hanchana S, Das D, Phyo AP, Lwin KM, Pukrittayakamee S, Lee SJ, Saisung S, Koecharoen K, Nguon C, Day NP, Socheat D, White NJ. Exploring the contribution of candidate genes to artemisinin resistance in Plasmodium falciparum. Antimicrob Agents Chemother 2010; 54: 2886-2892.

46. Mungthin M, Watanatanasup E, Sitthichot N, Suwandittakul N, Khositnithikul R, Ward SA. Influence of the pfmdr1 gene on in vitro sensitivities of piperaquine in Thai isolates of Plasmodium falciparum. Am J Trop Med Hyg 2017; 96: 624-629. 
